\title{
Relating fish distributions to physical characteristics of a tidal energy candidate site in the Banks Strait, Australia
}

\author{
Constantin Scherelis, Irene Penesis, Philip Marsh, Remo Cossu, Mark Hemer, Jeffrey Wright
}

\begin{abstract}
With the tidal energy industry moving towards commercial-scale developments, it is important to consider potential interactions between tidal energy converters (TECs) and the marine environment prior to the instalment of large-scale TEC arrays. The Banks Strait, a tidal channel located in the northeast of Tasmania, Australia, was identified as a promising candidate site for tidal energy by the Australian Tidal Energy (AUSTEn) project. To gain an understanding about potential overlap between TEC arrays and fish usage of the Banks Strait tidal channel, fish density distributions were estimated from hydroacoustic surveys during the tidal resource characterization campaign. Differences in fish density were examined according to bottom-depth, bottom - type, current speed, temperature and vertical distribution. Fish densities were significantly higher at night and displayed preferences for depths between $20-40 \mathrm{~m}$ and current speeds between $1.75-2 \mathrm{~m} / \mathrm{s}$. Fish density was generally highest in the bottom $10 \mathrm{~m}$ from the sea floor at all depths sampled. Variation by temperature and bottom-type sampled was not significant. Future studies involving long-term, stationary surveys of fish densities along with repeated surveys across different seasons would provide a more wholistic picture of fish distributions in the Banks Strait to inform developers about potential device encounter probabilities.
\end{abstract}

Keywords-Australian Tidal Energy, Banks Strait, environmental monitoring, fish density distribution, hydroacoustics

\section{INTRODUCTION}

A ustralia's commitment to the 2015 Paris Climate Agreement has produced a surge in the development of renewable technologies that aim to reduce Australia's greenhouse gas emissions. By 2020, Australia's renewable energy portfolio is targeted to reach $33 \mathrm{TWh}$, requiring $23.5 \%$ of Australia's electricity generation to be from renewable sources [1]. To meet this target, a total of 6000 MW of installed capacity from renewable sources is necessary. A largely untapped resource for renewable energy generation is found in the vast capacity for ocean renewable energy (ORE) presented by Australia's coastline in form of Tidal Energy Converters (TECs) and Wave Energy Converters (WECs). Current estimates indicate that ORE resources for wave and tidal far exceed Australia's electricity demand, which peaked at 229 TWh in 2017 [1 - 2].

In 2017, the Australian Renewable Energy Agency (ARENA), along with researchers at the Australian Maritime College (AMC), University of Tasmania, initiated the Australian Tidal Energy (AUSTEn) project. In partnership with the University of Queensland and Commonwealth Scientific and Industrial Research Organisation (CSIRO), the AUSTEn project aims to characterize high-flow tidal streams in Australia for their potential to develop tidal energy. If developed on a commercial scale, tidal energy has the potential to play a major role in Australia's future energy mix [3]. Regions characterized by near-shore, shallow, high-velocity tidal currents are targeted for tidal energy developments as they are in proximity to existing power grids, facilitate installation efforts more readily, and provide a highenergy extraction potential.
Manuscript received 16 March; accepted 26 March; published 8 Sept, 2020. This is an open access article distributed under the terms of the Creative Commons Attribution 4.0 licence (CC BY https://creativecommons.org/licenses/by/4.0/). This article has been subject to single-blind peer review by a minimum of two reviewers. This project is co-funded by the Australian Renewable Agency (ARENA) through the Advancing Renewables Programme (grant G00902), the Australian Maritime College, (University of Tasmania), the University of Queensland, CSIRO, our industry partners MAKO Tidal Turbines and SIMEC Atlantis Energy and our international collaborators Prof. Richard Karsten from Acadia University, Canada, and Dr Matt Lewis from Bangor University, UK.
C. Scherelis, I. Penesis and P. Marsh are with the Australian Maritime College, University of Tasmania, Launceston, Tasmania, 7250, Australia (email: constantin.scherelis@utas.edu.au). R. Cossu is with the School of Civil Engineering, University of Queensland, St Lucia, Queensland, 4072 Australia (email: r.cossu@uq.edu.au). M. Hemer is with the Commonwealth Scientific and Industrial Research Organisation, Hobart, TAS, 7001, Australia (email: mark.hemer@csiro.au). J. Wright is with the Institute of Marine and Antarctic Studies, University of Tasmania, Hobart, Tasmania, 7001, Australia (email: jeffrey.wright@utas.edu.au).

Digital Object Identifier https://doi.org/10.36688/imej.3.111-118 
The Banks Strait, located in the southeast region of the Bass Strait between Tasmania and Clark Island, Australia, was identified as an excellent candidate site for tidal energy developments (Fig. 1). Preliminary studies of this region involving a coarse-resolution hydrodynamic model show tidal currents exceeding $2.5 \mathrm{~m} / \mathrm{s}$ with a tidal range of $2 \mathrm{~m}$ [4 - 5], while sporadic bathymetry surveys by the Australian Navy indicate depths between 25-60 m. Along with its proximity to an existing power grid in the northeast of Tasmania, the Banks Strait offers potentially advantageous conditions for the installation, generation and transmission of electricity generated by TECs.

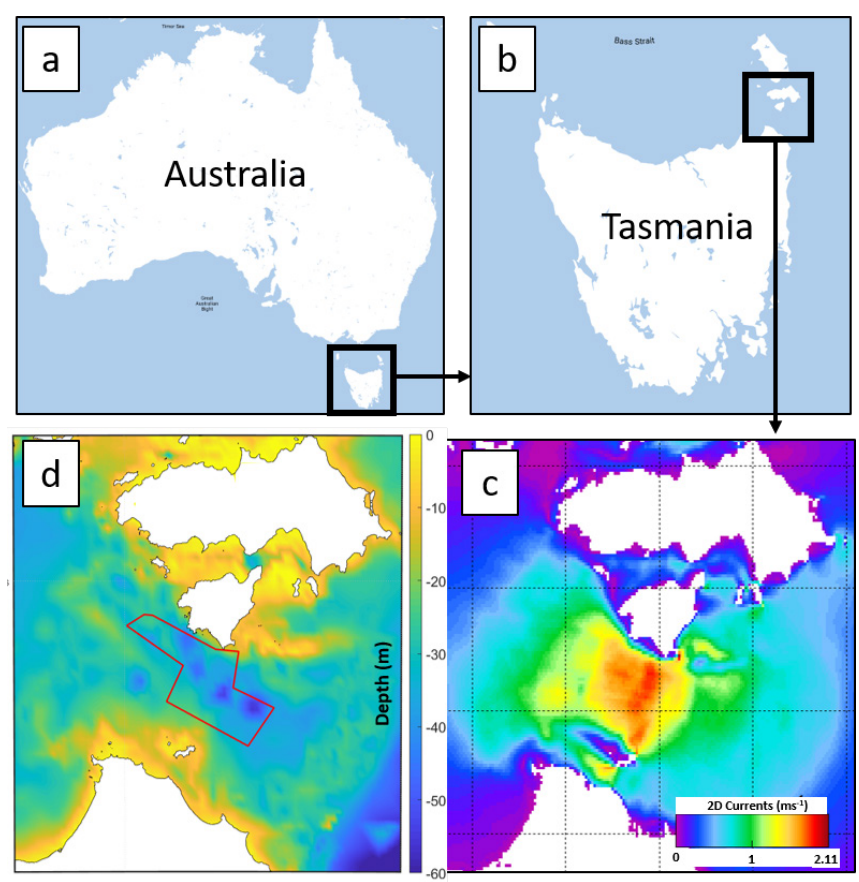

Fig. 1. Location of the Banks Strait ( $\mathrm{a} \& \mathrm{~b})$, simulated tidal currents in Banks Strait (c), and a bathymetry map of the Banks Strait with the region surveyed during the March 2018 field campaign highlighted in red (d).

As an emerging technology, the effects of tidal energy devices on the marine environment have yet to be fully described. One concern for tidal energy devices is the encounter probability between fish and turbines. Field studies monitoring fish behavior upon encountering turbine blades were conducted [6 - 8] and device encounter probability models were developed to address this concern [9]. No significant effects on fish behavior from single device deployments were concluded and fishstrike probability was determined to be less than $5 \%$ in a laboratory flume study by Castro-Santos and Haro [10]. However, both approaches recognized that encounter probability and subsequent effects to fish populations are a function of the number of fish present during the operational phases of the turbine. As the industry advances from single-device deployments to commercialscale arrays that include hundreds of turbines, the potential for fish and turbines to be co-located increase significantly. Additional concerns for commercial-scale TEC developments include population-level responses in fish by disrupting migratory pathways [11] and adding stressors in the form of underwater noise [12] and electromagnetic fields [13]. Potential impacts to the physical characteristics within a tidal channel have also been raised in form of reduced current speeds, altered water quality and nutrient supplies, and changes in sediment transport [14-16]. Addressing these concerns and quantifying potential impacts for comparison with other energy sources is a challenging, yet important step in evaluating the future of tidal energy [11].

Studies on the environmental impacts of tidal energy are limited and have not yet encompassed device effects on the marine environment to the full extent, especially for large-scale commercial developments [17]. In response to this uncertainty, environmental impact assessments (EIAs) must be conducted that inform about the marine animals, habitats and ecosystems at the tidal energy candidate sites and evaluate potential impacts of TECs to the marine environment. Fish density assessments at tidal energy candidate sites provide important insights for determining the impact of such devices on the marine environment.

Fish densities have been shown to vary by habitat, where different fish species display preferences for bottom type, depth, temperature, bathymetry and current speed [9, 18 - 19]. Environmental monitoring studies conducted at tidal energy sites to date suggest fish abundance is associated with tidal- and diel cycles and that the likelihood of fish encountering tidal energy devices changes seasonally [20 - 22]. It has also been established, in other oceanic environments, that fish presence and distribution are linked to a variety of hydrodynamic features ranging from small scales, such as turbulent eddies [23], to medium scales, such as internal waves [24], to large-scale oceanic convergence zones [25]. However, relationships between fish and hydrodynamic properties (e.g. currents and turbulence) in high-flow tidal habitats have yet to be fully described. The aim of this study is to examine relative fish density distributions throughout the Banks Strait tidal energy candidate site based on depth, current speed, bottom-type, and temperature.

\section{METHODS}

\section{A. Data collection}

A 16-day field campaign was undertaken by the AUSTEn project to characterize the tidal resource of the Banks Strait region from March 13 to March 29, 2018. Mobile hydroacoustic surveys of the study site were taken concurrent to field-campaign operations. Hydroacoustic sampling was conducted with a Simrad $120 \mathrm{kHz}, 7^{\circ}$ circular-beam transducer mounted to the vessel hull, operating at 0.2 millisecond pulse duration and a $2 \mathrm{~Hz}$ sampling rate. 
The region of interest (ROI) investigated during this campaign included a $173 \mathrm{~km}^{2}$ region within the Banks Strait tidal channel (Fig. 2). Sampling stations within the study region included 16 casts using an RBR Maestro Multi-Channel Logger for conductivity, temperature and depth (CTD) measurements. Eight of the CTD stations included Penetrometer casts measuring the penetration depth upon impact with the surficial seabed sediments. Maximum penetration depth is indicative for bottom-type, where penetration depths $<1 \mathrm{~cm}$ is typically rock, $>1 \mathrm{~cm}<$ $20 \mathrm{~cm}$ indicates sand and $>20 \mathrm{~cm}$ is most likely a mud or silt composition [26]. Each penetrometer station included three casts from which the mean penetration depth was taken. A drop-camera was used to confirm bottom-types inferred from penetration-depth measurements. Timing of survey transects within the ROI was subject to activities conducted by the AUSTEn project that included bathymetry surveys, instrument deployments for longterm monitoring, and station casts. Adverse weather also required the vessel to seek shelter near shore for several days. Two ADCP instrument were deployed during the field campaign, including a Teledyne RDI Workhorse 300 (station A) and a Nortek Acoustic Wave and Current profiler (station B).

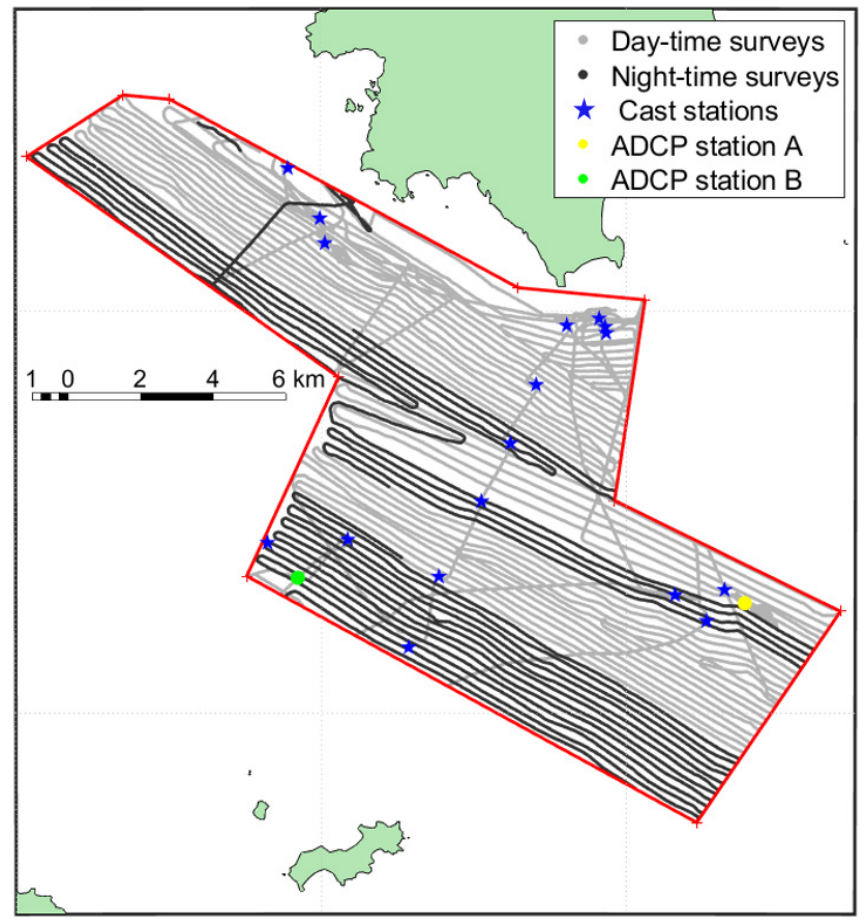

Fig. 2. Region surveyed in the Banks Strait during the March 2018 field campaign. Survey timing and sampling activities are highlighted. ADCP station 1 represents the Teledyne RDI Workhorse 300 and ADCP station 2 the Nortek Acoustic Wave and Current profiler.

\section{B. Data processing}

Survey tracks occurring within the ROI were extracted and processed in Echoview ${ }^{\circledR}$ software (10.0, Myriax, Hobart, Australia). Strong signals in the surface layer, likely caused by entrained air bubbles from turbulence and ship movement were removed by implementing a signal- dependent surface-line threshold (Fig. 3A). A bottomdetection line was also created to remove bottom returns and isolate the water column for continued data processing (Fig. 3B). A $-70 \mathrm{~dB}$ target-strength threshold was applied to remove non-fish targets contributing to the backscattered signal (e.g. suspended sediments, zooplankton). Survey tracks were split into $20 \mathrm{~m}$ distance bins $(\mathrm{N}=50,133)$ and processed for volume backscatter $\left(\mathrm{S}_{\mathrm{v}}\right)$ metrics. Bin size was based on a previous fish distribution study at a tidal energy candidate site in the Bay of Fundy [21]. $S_{v}$ is used to describe the density of organisms within a sampled volume of water and is the primary measurement tool for estimating fish densities and abundance in hydroacoustic studies [20 - 21, $27-28]$. $S_{v}$ represents the sum of backscatter received from all scatterers (i.e. targets) within a sampled volume of water and is expressed logarithmically in units of decibels ( $\mathrm{dB}$ re $\left.1 \mathrm{~m}^{-1}\right)$ or, in its linear domain $(\mathrm{sv})$, as $\mathrm{m}^{2} \times \mathrm{m}^{-3}$ defined as [28 $-29]$ :

$$
s_{v}=\frac{\sum \sigma_{b s}}{V}
$$

Where $\sigma_{b s}$ is the backscattering cross-section or reflective intensity of a target and $V$ the volume sampled. $V$ is a function of the equivalent beam angle $(\psi)$, an approximated angle at which $99 \%$ of energy is transmitted from a transducer ( $7^{\circ}$ in this case), and range squared (due to spherical spreading) [28]:

$$
V=\psi R^{2}\left(\frac{c \tau}{2}\right)
$$

Where $\mathrm{c}$ is the speed of sounds $(\mathrm{m} / \mathrm{s})$ and $\tau$ pulse duration (milliseconds). Mean volume backscatter $\left(s_{v_{\text {mean }}}\right)$ was calculated for each $20 \mathrm{~m}$ distance bin $(A)$, where the number of samples (s) per bin and sample volume $(V)$ varied according to vessel speed and activity, and depth [30].

$$
s_{v_{\text {mean }}}=\frac{\sum_{s}^{\text {in } A}\left(\varepsilon_{s} t_{s} s_{v s} V_{s}\right)}{\sum_{s}^{\text {in } A}\left(\varepsilon_{s} V_{s}\right)}
$$

Line- and target-strength thresholds were accounted for, where $\varepsilon=0$ if samples were outside of the surface- and bottom-line thresholds, and $t=0$ if samples were below the specified minimum target-strength threshold. $s_{v}$ values were then converted to its logarithmic form $\left[S_{v}=10 \times\right.$ $\left.\log \left(\mathrm{S}_{\mathrm{v}}\right)\right]$ and examined for differences according to diel stage, current speed and direction, bottom-depth (i.e. distance from the water surface to the seafloor) and vertical distributions within the water column. A separate processing step exported mean $S_{v}$ in $2 \mathrm{~m}$ depth-cell intervals for each $20 \mathrm{~m}$ distance bin (Fig. 3). Exported metadata included sampling time, GPS location and mean bottom- and surface-line depths per distance bin used to mask bottom- and surface backscatter. $S_{v}$ measurements within $100 \mathrm{~m}$ of each cast station were averaged and compared to the conditions present. 


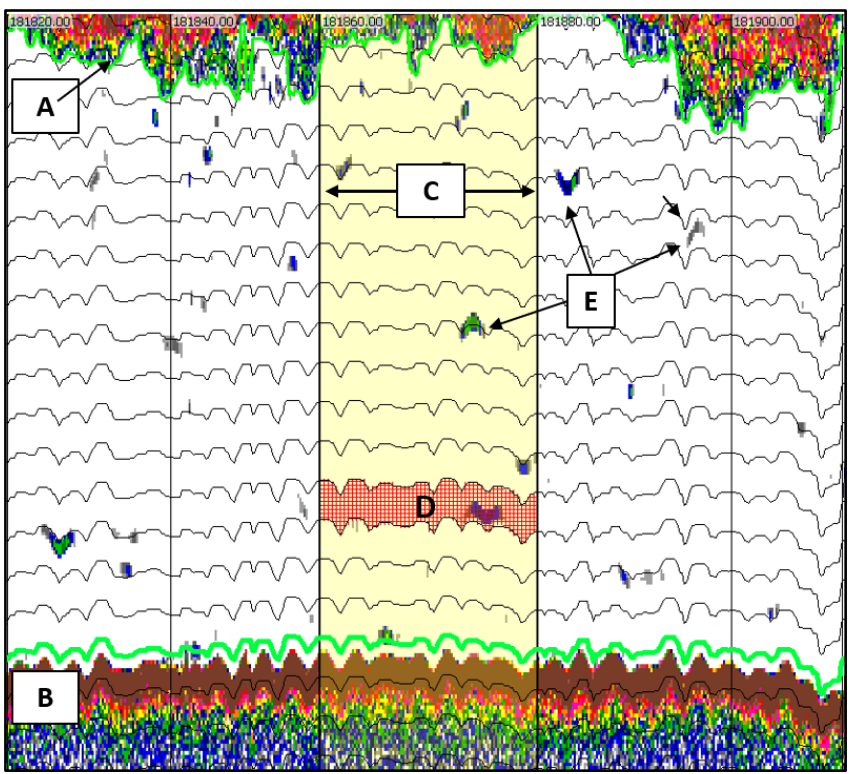

Fig. 3. Visualized processing steps for $\mathrm{S}_{\mathrm{v}}$ data extraction. A is the surface interference that includes (most likely) entrained air bubbles, $\mathbf{B}$ is the seafloor, $\mathbf{C}$ represents one $20 \mathrm{~m}$ distance bin, $\mathbf{D}$ shows a $2 \mathrm{~m}$ depth-cell within the $20 \mathrm{~m}$ distance bin, and $\mathbf{E}$ shows probable fish targets that contribute to the exported $\mathrm{S}_{\mathrm{v}}$ strength.

A two-dimensional, $400 \mathrm{~m}$ grid hydrodynamic model of the Banks Strait region was constructed as part of the AUSTEn tidal resource assessment campaign, with depthaveraged current speed and current direction simulated in $10 \mathrm{~min}$ intervals. The lateral open boundaries were forced using the TPXO7.2 global ocean model [31], with surface wind and sea level pressure forcing generated using the ERA5 dataset [32]. Modelled current speeds were matched to the respective time and location of each $20 \mathrm{~m}$ distance bin. Model performance was assessed by correlating modelled current speeds with in-situ measurements taken from two ADCP deployments in the study region during this field campaign (Fig. 2).

\section{Data analysis}

Data was subsampled into day-time and night-time surveys due to significant differences in $S_{v}$ that would mask any difference observed from the physical characteristics of the site. Surveys occurring between sunset and sunrise (19:30 - 07:00 AEDT) were grouped into night-time surveys $(\mathrm{N}=19,249)$, while any surveys outside of this period were grouped into day-time surveys $(\mathrm{N}=$ $30,884)$.

Current speed associated with each $20 \mathrm{~m}$ distance bin were grouped into $0.25 \mathrm{~m} / \mathrm{s}$ intervals, where the first interval represents mean $\mathrm{S}_{\mathrm{v}}$ for current speeds between 0 and $0.25 \mathrm{~m} / \mathrm{s}$ and the final interval includes currents between 2 and $2.25 \mathrm{~m} / \mathrm{s}$. Minimum current speed extracted from the hydrodynamic model based on survey time and location was $0.03 \mathrm{~m} / \mathrm{s}$, while the maximum was $2.08 \mathrm{~m} / \mathrm{s}$. Bottom-depth was grouped into $10 \mathrm{~m}$ intervals, where the minimum bottom-depth sampled throughout the study region was $14.76 \mathrm{~m}$ and the maximum depth was $74.87 \mathrm{~m}$.
Autocorrelation of $\mathrm{S}_{\mathrm{v}}$ among $20 \mathrm{~m}$ distance bins was removed by randomized data subsampling that allowed for each sampling unit to be treated as an independent measurement. Autocorrelation was found to be negligible after 40 lag-units for both day- and night-time sampling. As such, datasets were resampled into a randomized order where each data point was at least 40 units removed from the previous. The resampled day- and night-time datasets were tested for residual autocorrelation according to the Ljung-Box Q-test and found to have non-significant autocorrelation $(\mathrm{p}<0.05)$. This enabled changes in mean $\mathrm{S}_{\mathrm{v}}$ based on current speed, current direction and bottomdepth to be examined.

Vertical distribution of $S_{v}$ throughout the water column was explored by calculating the mean $\mathrm{S}_{\mathrm{v}}$ for all depth-cells that shared the same water depth (i.e. distance from water surface to depth-cell) and bottom-depth. For example, $\mathrm{S}_{\mathrm{v}}$ depth-cells close to the bottom between $26 \mathrm{~m}-28 \mathrm{~m}$ were only grouped with depth-cells that had comparable bottom-depths and not with regions that were significantly deeper, where $28 \mathrm{~m}$ would represent a midwater depth instead. Day- and night-time surveys were explored separately. Autocorrelation in the vertical distribution of $\mathrm{S}_{\mathrm{v}}$ was not of concern, as each cell presents a summary statistic (mean) that is representative of a collection of spatially and temporally independent samples.

Statistical analysis was carried out using the statistical toolbox in Matlab [33]. Significant differences in $\mathrm{S}_{\mathrm{v}}$ according to diel stage, depth, and current speed were examined using robust Analysis of Variance (ANOVA) tests in form of the Kruskal-Wallis test at the 1\% significance level $(p<0.01)$. The Kruskal-Wallis test examines whether variables included in the analysis share the same distribution, where a p-value $<0.01$ rejects the hypothesis that a shared distribution exists. Nonparametric testing was necessary as assumptions of normality were not met according to the KolmogorovSmirnov test at the $5 \%$ significance level $(\mathrm{p}<0.05)$.

\section{RESULTS}

Significant differences in $S_{v}$ values were observed during night-time sampling compared to day-time sampling with a large increase in backscatter occurring during the hour of sunset (19:00 - 20:00) and decreasing during the hour of sunrise (07:00 - 08:00). Median $\mathrm{S}_{\mathrm{v}}$ between the hours of 22:00 and 06:00 were shown to be consistently in the region of $-70 \mathrm{~dB}$, while median $\mathrm{S}_{\mathrm{v}}$ during day-time sampling were around the $-80 \mathrm{~dB}$ mark (Fig. 4). Sampling conditions with respect to current speed and direction, bathymetry and bottom-type were evenly represented during day- and night-time surveys. 


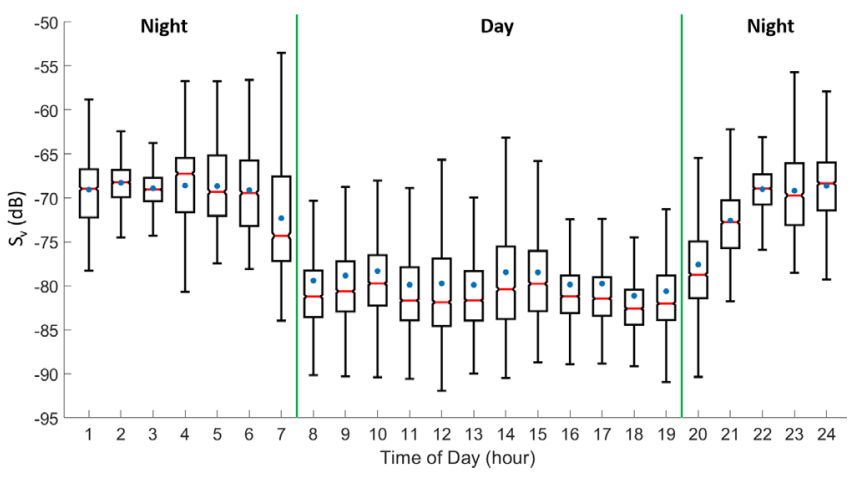

Fig. 4. Mean $\mathrm{S}_{\mathrm{v}}$ sampled at different hours of the day. Blue circles indicate means, red horizontal bars are medians, box height represents the $25^{\text {th }}$ and $75^{\text {th }}$ percentiles and whiskers the $10^{\text {th }}$ and $95^{\text {th }}$ percentiles. Green lines represent the mean sunrise and sunset times that occurred during the 16-day field campaign.

During daytime sampling, median $S_{\mathrm{v}}$ values varied from $-83.43 \mathrm{~dB}$ during low current speeds ( 0 to $0.25 \mathrm{~m} / \mathrm{s}$ ) over $81.17 \mathrm{~dB}$ during medium $(1-1.25 \mathrm{~m} / \mathrm{s})$ to $-80.04 \mathrm{~dB}$ during high current speed $(2-2.25 \mathrm{~m} / \mathrm{s})$ events. Night-time sampling saw a similar trend at significantly increased $S_{v}$ values, with $-70.56 \mathrm{~dB}$ during low, $-69.88 \mathrm{~dB}$ during medium and $-70.69 \mathrm{~dB}$ during high current events (1.75 $2.0 \mathrm{~m} / \mathrm{s})$. Highest median backscatter of $-66.73 \mathrm{~dB}$ was observed at night with currents between $1.5-1.75 \mathrm{~m} / \mathrm{s}$. Currents exceeding $2.0 \mathrm{~m} / \mathrm{s}$ did not occur during nighttime sampling. $S_{\mathrm{v}}$ was found to decrease steadily along the bottom-depth gradient, where deeper regions exhibited lower $S_{\mathrm{v}}$ during both day- and night-time sampling (Fig. 5). No significant differences in $S_{\mathrm{v}}$ were found as a result from current direction.

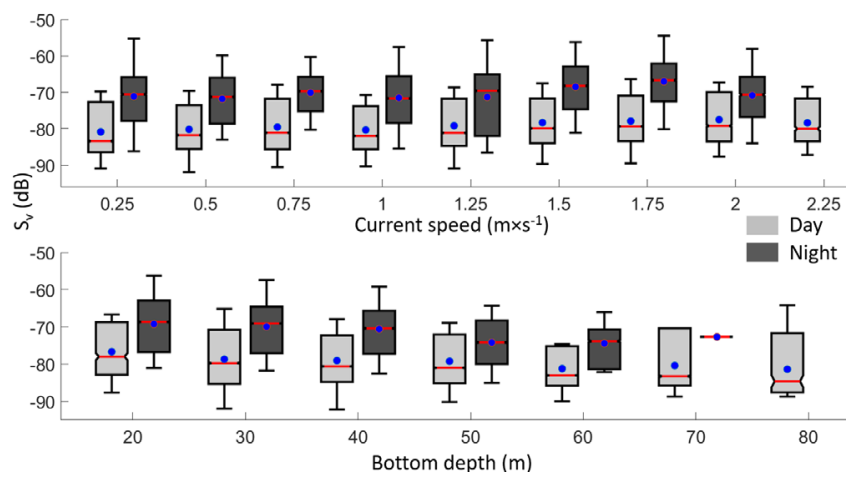

Fig. 5. Mean Sv grouped by diel stage, current speed, and bottomdepth. No depths above $70 \mathrm{~m}$ or current speeds above $2 \mathrm{~m} / \mathrm{s}$ were sampled during night-time surveys. Boxplot statistics are described in Fig. 4.

Further investigation into vertical distributions by bottom-depth revealed low $S_{v}$ in the top layer $(1.5 \mathrm{~m}-15$ $\mathrm{m})$, especially in regions with depths exceeding $22 \mathrm{~m}$ for day- and night-time sampling. $S_{v}$ increased with depth, where the highest values were sampled closest to the seafloor, especially in regions with depths between $15 \mathrm{~m}$ and $40 \mathrm{~m}$ (Fig. 6). Surveys in deeper pockets $(40 \mathrm{~m}-75 \mathrm{~m})$ exhibited a mid-water column layer where $S_{v}$ would increase from the surface to about $40 \mathrm{~m}$, then decrease $3 \mathrm{~dB}$ (day) and $4 \mathrm{~dB}$ (night) between the $40 \mathrm{~m}$ and $50 \mathrm{~m}$ layer before increasing again towards the bottom (Fig. 6).
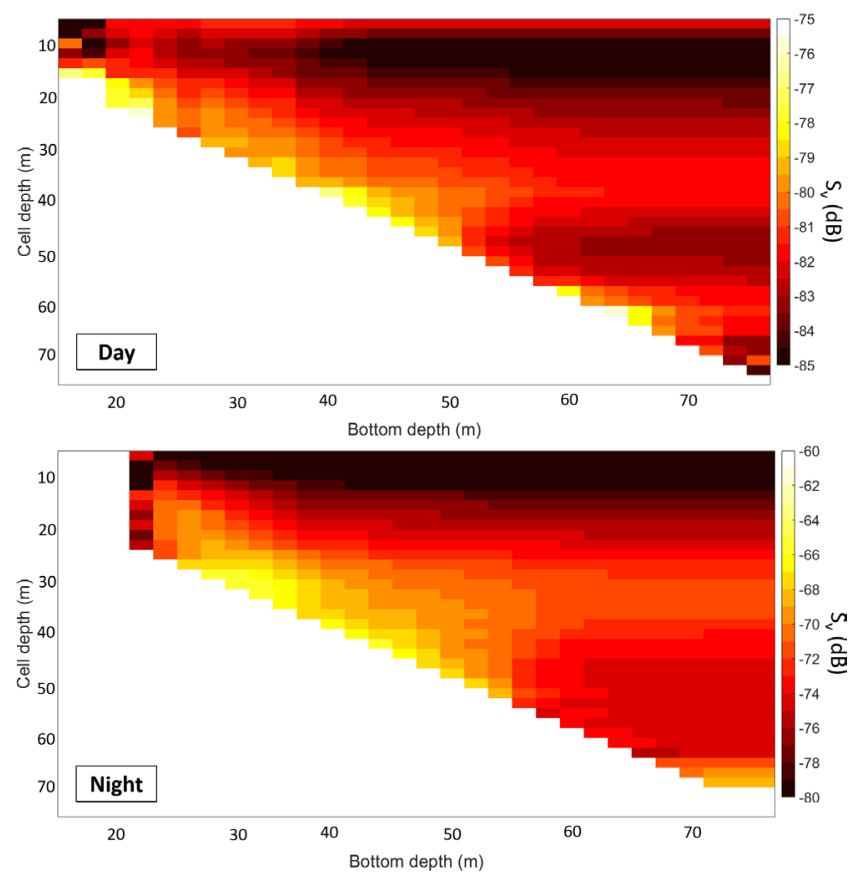

Fig. 6. Vertical distribution of $S_{v}$ throughout the water column at different depths. The $\mathrm{x}$-axis indicates the bottom-depth sampled, while the y-axis denotes the water column in $2 \mathrm{~m}$ cell depths. Bright colors indicate a higher concentration of fish targets in the water column. Note: color-scale change for night-time surveys.

Modelled current speeds correlated with in-situ measurements from ADCP station A at $\mathrm{R}=0.906$ and at ADCP station $\mathrm{B}$ at $\mathrm{R}=0.843$ (Fig. 7).
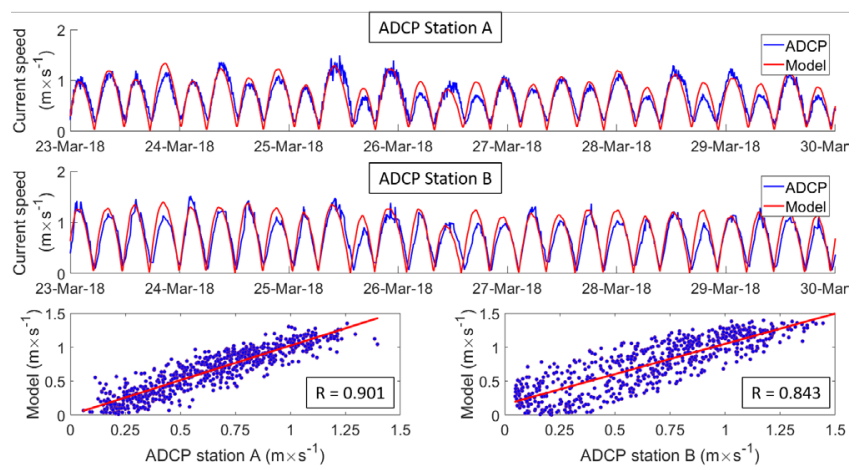

Fig. 7. Modelled current speed at station A and B compared to insitu ADCP measurements.

CTD casts were taken throughout the sampling site at depths between $23 \mathrm{~m}$ and $60 \mathrm{~m}$ (Fig. 8). Vertical changes in the CTD metrics measured for each cast were minimal (< $5 \%$ ) and the depth-averaged mean for each cast was taken (Table I). Temperature differences among stations varied between $18.14^{\circ} \mathrm{C}-19.70^{\circ} \mathrm{C}$. Differences in mean penetration depths by station measured $2.77 \mathrm{~cm}$ at station 6 , to $7.10 \mathrm{~cm}$ at station 8 . All stations were subject to a sandy bottom-types based on the methodology presented by [26]. Drop-camera observations confirmed these measurements with the addition that station 6 was characterized by rubble as well as sand. $S_{\mathrm{v}}$ values were significantly increased at station 1 and 2 where sampling 
occurred at night and site conditions displayed shallow depths $(\sim 25-30 \mathrm{~m})$ with increased temperatures (Table I).

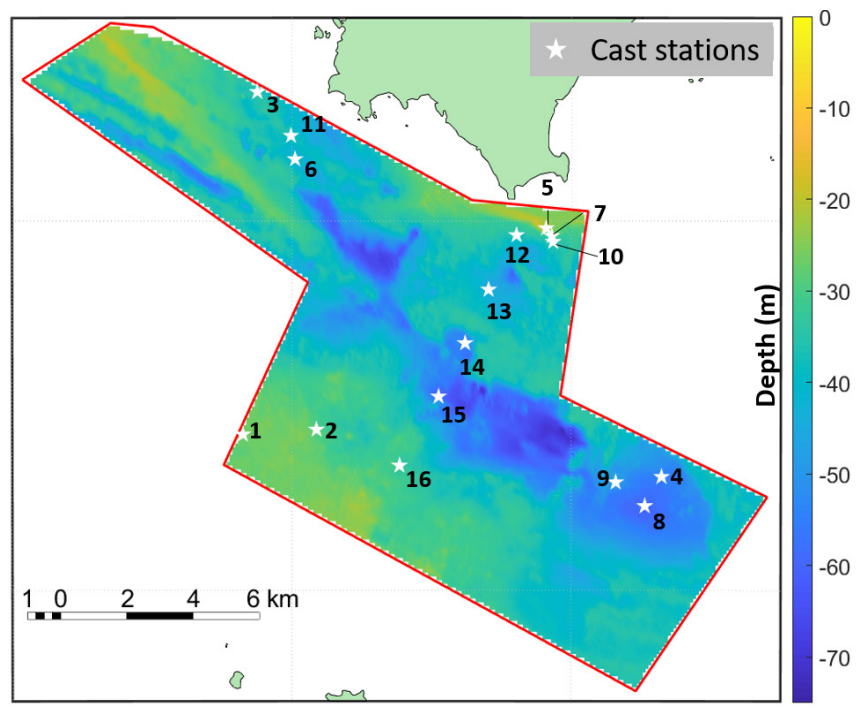

Fig. 8. Bathymetry of the study region and sampling stations for CTD and Penetrometer casts as presented in Table I.

TABLE I

DEPTH- AVERAGED RESULTS FROM SAMPLING STATIONS

\begin{tabular}{cccccc}
\hline & $\begin{array}{c}\text { Mean } \\
\text { Temp } \\
\text { Station }\end{array}$ & $\begin{array}{c}\text { Max } \\
\text { Depth } \\
(\mathrm{m})\end{array}$ & $\begin{array}{c}\text { Mean } \\
\mathrm{S}_{\mathrm{v}}\end{array}$ & $\begin{array}{c}\text { Diel } \\
\text { Stage }\end{array}$ & $\begin{array}{c}\text { Mean } \\
\text { Penetration } \\
\text { Depth }(\mathrm{cm})\end{array}$ \\
\hline 1 & 19.42 & 26.24 & -69.52 & Night & 6.37 \\
2 & 19.22 & 28.64 & -62.92 & Night & 4.03 \\
3 & 19.70 & 35.93 & -80.30 & Day & 3.63 \\
4 & 19.62 & 55.57 & -81.82 & Day & 5.50 \\
5 & 19.41 & 23.22 & -74.89 & Day & 6.90 \\
6 & 18.60 & 41.00 & -80.21 & Day & 2.77 \\
7 & 18.35 & 28.43 & -73.60 & Day & 6.90 \\
8 & 18.77 & 57.67 & -83.13 & Night & 7.10 \\
9 & 18.82 & 50.08 & -74.38 & Day & - \\
10 & 18.61 & 35.81 & -78.25 & Day & - \\
11 & 18.52 & 37.13 & -79.20 & Day & - \\
12 & 18.14 & 37.76 & -74.49 & Day & - \\
13 & 18.39 & 44.69 & -81.05 & Day & - \\
14 & 18.35 & 54.29 & -82.58 & Day & - \\
15 & 18.33 & 60.39 & -83.37 & Day & - \\
16 & 18.28 & 31.23 & -80.63 & Day & - \\
\hline
\end{tabular}

\section{DISCUSSION}

Fish densities throughout the Banks Strait were found to fluctuate based on the environmental conditions present and varied most notably by diel stage, followed by bottomdepth and current speed. Highest fish densities, in form of volume backscatter $\left(\mathrm{S}_{\mathrm{v}}\right)$, were present at night in regions with $15 \mathrm{~m}-30 \mathrm{~m}$ bottom-depth and depth-averaged current speeds between $1.75 \mathrm{~m} / \mathrm{s}$ and $2 \mathrm{~m} / \mathrm{s}$. Lowest fish densities were found at day in deep waters $(60 \mathrm{~m}-70 \mathrm{~m})$ during current speeds between $0 \mathrm{~m} / \mathrm{s}$ and $0.5 \mathrm{~m} / \mathrm{s}$. CTD stations with higher temperature also displayed higher fish densities, although sampling conditions for diel stage, bottom-depth, and current velocity must be considered. Vertical distribution in the water column were found to show increasing fish density with depth and the highest concentration of fish occurred in the bottom 2-6 m. However, mid-water column distribution differed by bottom-depth, where fish densities in regions beyond $50 \mathrm{~m}$ for day-time and $58 \mathrm{~m}$ during night-time surveys would decrease at $3 / 4$ of the water column depth before increasing to its respective maximum in the final quarter of the water column. Further investigation into vertical distribution changes based on current speed would show if fish are prone to change position in the water column according to current speeds and if certain depths are preferred during high- or low- current events.

Low fish densities found in the surface layer $(0-6 \mathrm{~m})$ may have been influenced by the 'surface line threshold' masking noise interferences caused by entrained air bubbles (Fig. 3A). The surface line was set to a minimum of $1.5 \mathrm{~m}$ and advanced to maximum of $18.72 \mathrm{~m}$ depending on strong backscatter extending from the surface. The median surface line depth was $2.21 \mathrm{~m}$ and extended beyond $6 \mathrm{~m}$ in only $3.6 \%$ of samples and beyond $10 \mathrm{~m}$ in only $0.27 \%$.

Findings from environmental monitoring studies focused on fish density distributions in other highpotential tidal energy sites showed some agreement and some disagreement with results from this study. For example, Viehman et al. [20] described the distribution of fish at the Fundy Ocean Research Center for Energy (FORCE) in the Bay of Fundy, Canada, using a bottommounted hydroacoustics platform. Fish density in this region was found to be mostly unaffected by diel stages and even displayed lower densities at night in the summer months. In addition, the vertical distribution of fish showed higher densities in the surface layer $(0-10 \mathrm{~m}$ during ebb) with an increase in the bottom layer $(25 \mathrm{~m}-$ bottom) also being present. Another study utilizing mobile hydroacoustic transects at the Bay of Fundy study site and shows the highest distribution of fish densities to be present in the bottom $10 \mathrm{~m}$ of the water column [21]. The Bay of Fundy study site is characterized by tidal currents exceeding $4 \mathrm{~m} / \mathrm{s}$, a tidal range of $12 \mathrm{~m}$, and a depth of $33 \mathrm{~m}$ during ebb. Differences in fish species composition and environmental conditions attribute to variations in fish density and distribution found among study sites and speaks to the fact that site-specific monitoring is important to adequately describe fish distributions at tidal energy candidate sites.

Vertical differences in CTD casts were minimal, as is to be expected in shallow $(<100 \mathrm{~m})$, well-mixed, turbulent systems. Penetrometer measurements indicate that a thin layer of sand is likely present in all regions sampled throughout the Banks Strait at varying depths [26]. Only station 3 included measurements with penetration depths 
of $0 \mathrm{~cm}$, indicating the presence of some rock or rubble, which was confirmed by the drop camera. Further investigation into the sediment layer based on hydrodynamic properties could provide valuable insights into sediment transport estimates for the Banks Strait region.

This study presents an overview of small-scale cyclical changes in fish density distributions (e.g. diel and tidal cycle) in the Banks Strait. However, seasonal changes in fish species composition have not been considered. Different fish species will interact differently with its environment, resulting in varying fish abundance, distribution and behavior, which must be recognized when investigating long-term interactions between tidal turbines and the marine environment [20 - 21]. Additionally, the location, design and size of tidal turbine(s) must be known to fully describe the spatial overlap with fish habitats. While the AUSTEn project has identified the Banks Strait as a well-suited candidate site for tidal turbines, exact turbine design and placement is decided by the industry looking to develop the site. Engineering constraints for different turbine designs will affect its exact placement and thus its spatial overlap with fish. It must also be recognized that spatial overlap between turbines and regions that exhibit high fish densities is not necessarily an indication for fish injury or mortality rates. Swimming behavior of fish in close proximity to an operating turbine will inform about fishstrike probabilities, which can then be extrapolated to the spatial distribution of fish at tidal energy sites.

Fish assemblage studies along the Tasmanian coast are consistent with the results from this study. $30 \mathrm{~km}$ east of the Banks Strait study site lies the Flinders Commonwealth Marine Reserve that has been studied extensively for its fish species assemblage [18]. These studies have found higher fish abundance and species richness, as well as larger individuals to be present at night and in shallow waters [19]. Reef-associated bottom habitats also showed higher species richness, while sediment habitats showed species at significantly higher tropic levels [18]. The most common fish species of the shallow, reef-associated habitat assemblage included Degan's leatherjacket (T. degeni), silverbelly ( $P$. melbournensis), jackass morwong ( $N$. macropertus), velvet leather jackets ( $M$. scaber), and draughtboard shark (C. laticeps). The most common fish species of the shallow sediment-associated habitat assemblage included the common gurnard perch $(N$. scorpaenoides), sand flathead (Platycephalus bassensis), gummy shark (Mustelus antarcticus), and the tiger flathead (Platycephalus richardsoni).

\section{CONCLUSION}

This study provides an overview of fish density distributions in the Banks Strait tidal energy candidate site (Australia) with consideration given to diel stage, depth, current speed and direction, temperature and bottomtype. Significant density changes between day- and nighttime surveys were observed, with differences in bottomdepth and current speed also being evident. Vertical distributions showed higher densities towards the bottom. Bottom-type and temperature had negligible impacts on fish densities observed. Overlaying favorable areas for turbine installation with physical conditions that display high fish densities will help determine the potential for TECs and local fish populations to interact and help mitigate potential device effects to the marine environment early in the development process. Further studies that address seasonality in the Banks Strait region are intended. Mobile transects at different times throughout the year will inform about seasonal changes to fish density distributions that may result from a varying fish species assemblage. Furthermore, a long-term, stationary study involving a bottom-mounted platform sampling fish and tidal currents concurrently will give insights into fine-scale relationships between fish and currents over several months.

\section{ACKNOWLEDGEMENT}

We would like to thank Camille Couzi, Dr Alistair Grinham, Christelle Auguste, and Dr Jean-Roch Nadar for their support and valuable contributions to this project.

\section{REFERENCES}

[1] M. A. Hemer, R. Manasseh, K. L. McInnes, I. Penesis, and T. Pitman, "Perspectives on a way forward for ocean renewable energy in Australia," Renewable Energy, vol. 127, pp. 733-45, 2018.

[2] Enerdata, "Electricity Production 2018," Global Energy Statistical Yearbook. [Online] Available at: https://yearbook.enerdata.net/electricity/world-electricityproduction-statistics.html

[3] I. Penesis, M. Hemer, R. Cossu, J. Hayward, J.R. Nadar, U. Rosebrock, A. Grinham, S. Sayeef, P. Osman, P. Marsh, C. Couzi, "Tidal energy in Australia - assessing resource and feasibility to Australia's future energy mix" Asian Wave and Tidal Energy Conference (AWTEC) 2018 Proceedings, 2018, pp. 507.

[4] S. Behrens, D. Griffin, J. Hayward, M. Hemer, C. Knight, S. McGarry, P. Osman, J. Wright, “Ocean Renewable Energy: 20152050: an analysis of ocean energy in Australia", in: Commonwealth Scientific and Industrial Research Organisation Report, 2012, p. 212.

[5] R. Rahimi, I. Penesis, M. Hemer, L. Mason, G. Thomas, "Characterization of the tidal current resource in Tasmania," Asian Wave and Tidal Energy Conference (AWTEC), 2014.

[6] M.S. Bevelhimer, C. Scherelis, J. Colby, M.A. Adonizio. "Hydroacoustic Assessment of Behavioral Responses by Fish upon Encountering an Operating Tidal Turbine in the East River, New York," Transactions of the American Fisheries Society, vol. 146, pp. 1028-1042. 2017.

[7] H. Viehman, G.B. Zydlewski, "Fish interaction with a commercial-scale tidal energy device in the natural environment," Estuaries and Coasts, vol. 38, pp. 241-252, 2015.

[8] S. Aamaral, D. Giza, B. McMahon, "Evaluation of survival and behavior of fish exposed to an axialflow hydrokinetic turbine," Electric Power Research Institute, Palo Alto, California. Report 3002003911, Apr. 2014. [Online] Available: https://tethys.pnnl.gov/sites/default/files/publications/EPRI_Re port 2014.pdf 
[9] L. Hammer, S. Eggertsen, J. Andersson, R. Ehnberg, M. Arvidsson, M. Gullstrom, and S. Molander, "A probabilistic model for hydrokinetic turbine collision risks: exploring impacts on fish," PLoS One, vol. 10, e0117756, 2015.

[10] T. Castro-Santos, A. Haro, "Survival and behavioral effects of exprosure to a hydrokinetic turbine on juvenile Atlantic Salmon and adult American Shad," Estuaries and Coasts, vol. 38, pp. 203214, 2015.

[11] A. Copping, N. Sather, L. Hanna, J. Whiting, G. Zydlewski, G. Staines, A. Gill, I. Hutchinson, A. O'Hagan, T. Simas, J. Bald, C. Sparling, J. Wood, E. Masden, "Annex IV 2016 State of the Science Report: Environmental Effects of Marine Renewable Energy Development Around the World," Apr. 2016. [Online] Available:

https://tethys.pnnl.gov/sites/default/files/publications/AnnexIV-2016-State-of-the-Science-Report_LR.pdf.

[12] M.P. Schramm, M. Bevelhimer, C. Scherelis, "Effects of hydrokinetic turbine sound on the behavior of four species of fish within an experimental mesocosm," Fisheries Research, vol. 190, pp. 1-14. 2017.

[13] G.W. Boehlert, A.B. Gill, "Environmental and ecological effects of ocean renewable energy development: a current synthesis," Oceanography, vol. 23, no. 2, pp. 68-81, 2010.

[14] T. Wang, Z. Yang, A. Copping, "A modeling study of the potential water quality impacts from in-stream tidal energy extraction," Estuaries and Coasts, vol. 38, pp. 173-186, 2015.

[15] S. Neill, E. Litt, S. Couch, A. Davies, "The impact of tidal stream turbines on large-scale sediment dynamics," Renewable Energy, vol. 34, pp. 2803-2812, 2009.

[16] S.J. Couch, I.G. Bryden, "Large-scale physical response of the tidal system to energy extraction and its significance for informing environmental and ecological impact assessment," in Proceedings Oceans 2007-Europe International Conference, 2007, vol. 1-3, pp. 912-916.

[17] A. Copping, "The State of Knowledge for Environmental Effects: Driving Consenting/Permitting for the Marine Renewable Energy Industry," Pacific Northwest National Laboratory (PNNL). Jan. 2018. [Online] Available: https://tethys.pnnl.gov/sites/default/files/publications/The\%20S tate $\% 20$ of $\% 20$ Knowledge $\% 20$ Driving $\% 20$ Consenting $\% 20$ Permi ting $\% 20$ for $\% 20$ the $\% 20$ MRE.pdf.

[18] N.A. Hill, N. Barrett, E. Lawrence, J. Hulls, J.M. Dambacher et al. "Quantifying Fish Assemblages in Large, Offshore Marine Protected Areas: An Australian Case Study," PLoS ONE, vol. 9, e110831, 2014.

[19] P. Last, "Aspects of the ecology and zoogeography of fishes from soft bottom habitats of the Tasmanian shore zone," PhD. Dissertation, University of Tasmania, 1983.

[20] H. Viehman, T. Boucher, A. Redden, „Winder and summer differences in probability of fish encounter (spatial overlap) with MHK devices," presented at the 12th European Wave and Tidal Energy Conference (EWTEC), 2017 in Cork, Ireland.

[21] A. Daroux, G. Zydlewski, "Fish Monitoring to Assess Effects of a Turbine in a Tidal Energy Development Site," presented at the 12th European Wave and Tidal Energy Conference (EWTEC), 2017, in Cork, Ireland.

[22] F.M. Keyser, J.E. Broome, R.G. Bradford, B. Sanderson, A.M. Redden, "Winter presence and temperature-related diel vertical migration of striped bass (Morone saxatilis) in an extreme highflow passage in the inner Bay of Fundy," Canadian Journal of Fisheries and Aquatic Sciences, vol. 73, pp.1777-1786, 2016.

[23] S. Benjamins, A. Dale, G. Hastie, J. Waggitt, M.A. Lea, B. Scott, B. Wilson, "Confusion Reigns? A Review of Marine Megafauna Interactions with Tidal-Stream Environments." Oceanography and marine biology, vol. 53, pp. 1-54. 2015.

[24] C. Embling, J. Sharples, E. Armstrong, M. Palmer, B. Scott, "Fish behavior in response to tidal variability and internal waves over a shelf sea bank," Progress in Oceanography, vol. 117, pp. 106-117, 2013.

[25] O.R. Godø, A. Samulelsen, G.J. Macaulay, R. Patel, S.S. Hjøllo et al., "Mesoscale Eddies Are Oases for Higher Trophic Marine Life," PLoS ONE, vol. 7, e30161, 2012.

[26] N. Stark and A. Kopf, "Detection and quantification of sediment remobilization processes using a dynamic penetrometer," Oceans' 11 MTS/IEEE Kona, Waikoloa, HI, 2011, pp. 1-9.

[27] S. Fraser, V. Nikora, B.J. Williamson, B.E. Scott, "Automatic active acoustic target detection in turbulent aquatic environments," Limnology and Oceanography: Methods, vol. 15, no. 2, pp. 184-199, 2017.

[28] S.L. Parker-Stetter, L.G. Rudstam, P.J. Sullivan, D.M. Warner, "Standard operating procedures for fisheries acoustic surveys in the Great Lakes," Great Lakes Fishery Commission Special Publication, 2009.

[29] J. Simmonds, D.N. MacLennan, "Underwater Acoustics," in Fisheries acoustics: theory and practice. Blackwell Science 2005, ch. 4, pp. 20-69.

[30] Echoview Software Pty Ltd Echoview software, version 9.0.323.34916. Echoview Software Pty Ltd, Hobart, Australia. [Online].

Available: https://support.echoview.com/WebHelp/Reference/Algorithms/ Analysis_variables/Sv_mean.htm

[31] G.D. Egbert, E.Y. S.Y. Erofeeva, "Efficient inverse modeling of barotropic ocean tides." Journal of Atmospheric and Oceanic Technology, vol. 19, no. 2, pp. 183-204, 2002.

[32] Copernicus Climate Change Service (C3S), "ERA5: Fifth generation of ECMWF atmospheric reanalyses of the global climate." Copernicus Climate Change Service Climate Data Store (CDS), Accessed Feb. 2019. [Online] Available: https://cds.climate.copernicus.eu/cdsapp\#!/home

[33] MATLAB and Statistics Toolbox Release 2018a, The MathWorks, Inc., Natick, Massachusetts, United States. 